\title{
Dlaczego grupom udaje się podejmować działania? Przedstawienie teorii działań zbiorowych Elinor Ostrom
}

\author{
Maciej Grodzicki*
}

Streszczenie: M. Olson w „Logice działania zbiorowego” zauważył, że działania jednostek na rzecz grupy często
stoją w konflikcie z ich egoistycznymi interesami. Utrudnia to podejmowanie działań zbiorowych
i powoduje, że optymalne z punktu widzenia całej grupy rezultaty niekoniecznie są osiągane. Z tego
względu, teoria wyjaśniająca mechanizmy podejmowania działań zbiorowych ma doniosłe znac-
zenie. Celem niniejszego artykułu jest teoretyczne wyjaśnienie zachodzenia działań zbiorowych na
gruncie współczesnego instytucjonalizmu, a przede wszystkim myśli E. Ostrom.
Niniejszy artykuł ma charakter stricte teoretyczny. Objaśniono w nim założenia teorii racjonalnego
wyboru I i Il generacji i przedstawiono, w jaki sposób przekładają się one na mechanizmy działań
zbiorowych. Współczesna teoria działań zbiorowych E. Ostrom rozwija koncepcję działającej jed-
nostki o elementy wyjaśniające interakcje i długookresowe relacje pomiędzy podmiotami - normy,
instytucje i kapitał społeczny. Dzięki temu jest w stanie spójnie opisać instytucjonalizację sytuacji
działania zbiorowego i może byćaplikowana do wyjaśniania różnorodnych problemów społecznych. Słowa kluczowe: działania zbiorowe, kapitał społeczny, teoria racjonalnego wyboru, instytucjonalizm, Elinor Ostrom.

\section{Wprowadzenie}

Celem niniejszego artykułu jest teoretyczne wyjaśnienie zachodzenia działań zbiorowych na gruncie współczesnej ekonomii instytucjonalnej, a przede wszystkim myśli Elinor Ostrom. Pojęcie "działań zbiorowych" dotyczy aktywności podejmowanej przez różnej wielkości grupy podmiotów - ludzi lub organizacji, połączonych wspólnym celem, który w ten sposób może zostać łatwiej osiągnięty, niż w przypadku działań indywidualnych [Ostrom, Ahn, 2007]. Okazje do podejmowania działań zbiorowych odnajdujemy przy okazji wielu problemów społecznych i ekonomicznych, począwszy od budowy drogi lokalnej, poprzez tworzenie krajowego systemu innowacji, a kończąc na próbach ograniczenia globalnego ocieplenia klimatycznego. Skuteczność grup i społeczeństw do podejmowania działań zbiorowych przekłada się na ich rezultaty ekonomiczne, osią- gany poziom dobrobytu, a także na spójność społeczną [ibidem].

Działania jednostek na rzecz grupy często stoją w konflikcie $z$ ich egoistycznymi interesami, a krótkookresowe indywidualne korzyści członków grupy stanowią barierę do osiągnięcia wspólnego celu w dłuższym okresie. Istotą problemu działania zbiorowego jest właśnie ten konflikt, który powoduje, że optymalne z punktu widzenia całej grupy rezultaty niekoniecznie są osiągane [Ostrom 2000]. Z tego względu, teoria wyjaśniająca mechanizmy podejmowania działań zbiorowych ma doniosłe znaczenie, wykraczające poza jedynie cele poznawcze. Przekłada się ona bo-

\section{* Maciej Grodzicki}

Instytut Ekonomii, Finansów i Zarządzania

Uniwersytet Jagielloński

ul. Łojasiewicza, 430-348 Kraków

e-mail: grodzicki.maciej@gmail.com 
wiem istotnie także na praktykę zarządzania organizacjami społecznymi.

Współczesne teorie działań zbiorowych są, z jednej strony, silnie osadzone w koncepcjach działającej jednostki. Koncepcje M. Olsona i E. Ostrom wywodzą się z metodologicznego indywidualizmu oraz teorii racjonalnego wyboru, lecz przynależą do dwóch generacji tego paradygmatu badawczego. Z drugiej strony, zależność jednostki od decyzji innych członków zbiorowości powoduje, że problem działań zbiorowych jest jakościowo różny od regularnych, indywidualnych działań rynkowych i potrzebuje oddzielnego podejścia badawczego. Koncepcja działającej jednostki musi zostać rozwinięta o elementy wyjaśniające interakcje i długookresowe relacje pomiędzy podmiotami. W artykule objaśniono założenia teorii racjonalnego wyboru I i II generacji oraz przedstawiono, w jaki sposób przekładają się one na mechanizmy działań zbiorowych. Jak pokazano, współczesna teoria jest w stanie spójnie opisać instytucjonalizację sytuacji działania dzięki przyjęciu realistycznej wizji jednostki i rzeczywistości społecznej.

Niniejszy artykuł ma charakter stricte teoretyczny. Przedstawia on elementy filozofii politycznej E. Ostrom i jej męża V. Ostroma, które mocno oddziałują na kierunki rozwoju współczesnego instytucjonalizmu. Prace teoretyczne Ostromów dotyczyły ogólnego problemu działań zbiorowych, zaś zaproponowane przez nich kategorie pojęciowe mogą być aplikowane do wyjaśniania różnorodnych problemów społecznych.

E. Ostrom w swoich badaniach empirycznych skupiała się na zagadnieniu zarządzania wspólnymi zasobami (ang. common-pool resources). Natomiast Pieliński [2014] wykorzystuje jej koncepcje, w twórczym połączeniu z podejściem A. Sena, do analizy problemu ubóstwa. Wydaje się również, że teoria działań zbiorowych może być użyteczna do zrozumienia funkcjonowania sektora ekonomii społecznej. Choć jego podmioty angażują się w konkurencję rynkową i podejmują w codziennej aktywności ryzyko, to jednocześnie realizują pozamonetarne cele, zaś ich członkom przyświecają motywacje, których nie da się sprowadzić do chęci osiągnięcia wynagrodzenia lub zysku [Defourny, Nyssens, 2013]. Podmioty ekonomii społecznej wyróżniają się również organizacyjnie - ich funkcjonowanie opiera się często o partycypacyjne działania zbiorowe, silnie zakorzenione w lokalnej społeczności [Hausner, 2007]. Jak pokazują Nyssens i Defourny [2014], istota działań ekonomicznych, które niekoniecznie prowadzą do zysków czy zasobów rynkowych opiera się na takich wartościach jak solidarność czy wzajemność. Wszystkie te elementy, jak zostanie pokazane, są obecne w teorii Ostrom. Może ona zatem stanowić punkt wyjścia dla dalszych rozważań na temat ekonomii społecznej.

W drugiej części tekstu przedstawiono wnioski z tradycyjnej teorii działań zbiorowych M. Olsona. Część trzecia zawiera krytykę tego podejścia przez nurt instytucjonalny oraz jego własne propozycje ontologiczne i metodologiczne. W części czwartej zaprezentowano współczesną teorię działań zbiorowych E. Ostrom, ze szczególnym uwzględnieniem jej wybranych elementów - norm, instytucji i kapitału społecznego. Część piąta zawiera podsumowanie rozważań oraz ich ocenę ze strony autora artykułu.

\section{Ponura logika działań zbiorowych}

Zagadnienie działań zbiorowych absorbowało już wczesnych myślicieli politycznych i ekonomicznych, m.in. Davida Hume'a, Alexandra Hamiltona, Jamesa Madisona i Johna Stuarta Milla. W ich koncepcjach filozoficznych i politycznych pojawiały się bardzo istotne spostrzeżenia o konflikcie pomiędzy realizacją interesu grupowego, a interesami poszczególnych członków grupy. Ów konflikt analizowany był w kategoriach znanych współcześnie pod nazwami dylematu więź- 
nia' lub problemu koordynacji ${ }^{2}$ [Dougherty, 2003, s. 240-244].

Pierwszym autorem, który stosował szeroko paradygmat racjonalnego wyboru do analizy działań zbiorowych był M. Olson. Odrzucił on tradycyjne ekonomiczne i socjologiczne teorie grup, które abstrahowały od działań jednostkowych i przyjmowały podejście holistyczne lub szukały pozaracjonalnych przyczyn istnienia grup [Dixit, 1999]. Olson swoją analizę rozpoczynał natomiast od postawienia pytania, czy w ogóle do tych działań dojdzie. Jak zauważył R. Hardin [1982, s. 1-2], dopiero przyjęcie przez Olsona metodologicznego indywidualizmu pozwoliło na rozprawienie się z błędami założenia, obecnymi w podejściach holistycznych. Olson konsekwentnie analizował rzeczywistość w kategoriach teorii ekonomicznych, a jego podejście badawcze było umocowane w paradygmacie teorii racjonalnego wyboru (TRW) I generacji. Podstawowym wyróżnikiem działającej jednostki jest u Olsona ciągła kalkulacja - porównywanie oczekiwanych korzyści z poniesionymi kosztami lub z włożonym w działanie wysiłkiem [Olson, 2012, s. 76-82].

Stosując TRW I generacji, dochodzi się do wniosku, że grupa powstanie tylko i wyłącznie wtedy, jeśli będzie to w interesie kilku (przynajmniej dwóch) osób. Natomiast jednostki będą miały interes w stworzeniu grupy, tylko jeśli działanie zbiorowe pozwoli lepiej zrealizować dany cel niż działanie indywidualne. Jednakże z faktu, że jakaś grupa osób posiada wspólny cel, który może zostać zrealizowany tylko przez działanie zbiorowe, nie wynika

\footnotetext{
Jest to sytuacja decyzyjna, w której gracze podejmują decyzje niezależnie od siebie, a struktura wypłat powoduje, że każdemu z nich z osobna opłaca się oszukiwać drugiego. Niestety, jeśli obaj gracze oszukują jednocześnie, to każdy z nich wypada gorzej, niż gdyby obaj działali nieegoistycznie.

2 Jest to problem podobny do dylematu więźnia, z zastrzeżeniem, że uczestnicy interakcji podejmują działania w oparciu o oczekiwania co do zachowania drugiej strony. W zależności od posiadanych oczekiwań, występuje tu możliwość zachowań nieegoistycznych, a zatem dobro zbiorowe może zostać dostarczone.
}

jeszcze, że takie działanie zostanie rzeczywiście podjęte. W tym miejscu zarysowuje się bodajże największy wkład Olsona w teorię nauk społecznych - pokazał on, że: „[t]eza, że grupy będą działały zgodnie ze wspólnym, czyli grupowym interesem, nie jest logiczną implikacją założenia, że ich członkowie będą racjonalnie dążyli do indywidualnych korzyści - w istocie jest z takim założeniem sprzeczna" [Olson, 2012, s. 10]. Przyczyny tego stanu rzeczy są określane przez niektórych „ponurą logiką działania zbiorowego" [Chmielewski, 2011, s. 148].

Realizacja celu grupy może być rozpatrywana w kategoriach dobra zbiorowego (ang. collective good) ${ }^{3}$ - przynosi ona bowiem korzyści wszystkim jej członkom. Oznacza to, po pierwsze, że działania jednostki na rzecz grupy powodują rozproszenie korzyści - każda osoba otrzyma jedynie część ogólnej korzyści, która jest wynikiem jej działania. Po drugie, korzyści z ich dostarczenia są dostępne również dla tych członków grupy, którzy nie uczestniczyli w działaniach na rzecz pozyskania dobra. Dobra zbiorowe charakteryzują się zatem brakiem możliwości (lub wysoką nieopłacalnością) wyłączenia pojedynczych osób z konsumpcji: „muszą być dostępne dla wszystkich, jeśli mają być w ogóle dostępne" [Olson, 2012, s. 23].

Taka sytuacja stwarza bodźce do „jazdy na gapę" - pojedynczym członkom grupy nie opłaca się uczestniczyć w działaniach grupy, gdyż:

- wycofanie się z działania na rzecz grupy zmniejszy indywidualną konsumpcję jedynie o ułamek ogólnych korzyści z tego działania,

- mogą liczyć na udział w podziale korzyści z działań pozostałych członków [ibidem, s. 47].

Olson dowodził, że jeśli w ten sposób będą kalkulować wszyscy członkowie gru-

\footnotetext{
Analogicznie, jeśli rzecz dotyczy szerokiej społeczności, cel możemy określić mianem dobra publicznego (public good).
} 
py, to może się okazać, że nikt nie podejmie działań i dobro zbiorowe w ogóle nie zostanie dostarczone. $W$ rezultacie znajdujemy się w punkcie, który stanowi równowagę Nasha (żaden z uczestników z osobna nie ma bodźców do zmiany swojej decyzji), zamiast w punkcie optimum społecznego [ibidem, s. 38-43]. Jest to podstawowy wniosek z teorii Olsona, zwany również ,tezą zerowego udzia$\nmid u^{\prime \prime}$ (ang. zero contribution thesis) [Ostrom, 2000], który przeczy tradycyjnym poglądom o automatycznych działaniach jednostek na rzecz grup.

Działania zbiorowe stanowią zatem przykład dylematu społecznego - sytuacji, w której jednostki działają racjonalnie z punktu widzenia indywidualnego, ale przez to nie jest osiągana racjonalność zbiorowa ${ }^{4}$. Inny autor tego nurtu, G. Hardin (który tę samą logikę funkcjonowania grupy zastosował do problemu zwanego „tragedią wspólnego pastwiska"), w swoim artykule przywołał cytat, który dobrze oddaje ponurą logikę działań zbiorowych: „Istotą dramatycznej tragedii nie jest nieszczęście. Jej istota leży w podniosłej, bezlitosnej kolei rzeczy" [Whitehead, 1948, cyt. za: Hardin, 1968, s. 1244].

W dalszej kolejności Olson wskazywał na mechanizm, dzięki któremu grupy są często w stanie przełamywać omówiony paradoks i podejmować zbiorowe działanie: jest to dostarczanie bodźców selektywnych, a więc takich, które są związane z rzeczywistym zaangażowaniem konkretnych jednostek w działania grupy. Bodźce selektywne mogą przyjmować postać kar bądź nagród różnego rodzaju. Ustanowienie mechanizmów kar i nagród, które same w sobie są dobrem zbiorowym, nie jest zadaniem łatwym. W małych grupach jest ono możliwe dzięki komunikacji i wzajemnej obserwacji działań, staje się to zaś

\footnotetext{
4 Późniejsi autorzy dowiedli, że logikę działania zbiorowego w ujęciu Olsona można przełożyć na język teorii gier jako n-osobowy dylemat więźnia i to podejście dominowało w dalszym rozwoju teorii [Hardin, 1971, 1982].
}

o wiele trudniejsze wraz ze wzrostem liczebności grupy.

\section{Krytyka tradycyjnej teorii działań zbiorowych}

Przewidywania tradycyjnej teorii działań zbiorowych były podważane na gruncie empirycznym. Nie znajdywały one potwierdzenia w eksperymentach oraz w badaniach terenowych, które wykazywały poziomy współpracy systematycznie wyższe od wartości przewidywanych teoretycznie. Okazywało się, że - wbrew tezie „zerowego zaangażowania" - ludzie są skłonni do podejmowania działań na rzecz dobra zbiorowego oraz, że w rzeczywistości nie mamy do czynienia z homogenicznymi racjonalnymi egoistami, ale ludzie wykazują zróżnicowaną skłonność do kooperacyjnych zachowań [Ostrom, 1986; 1987; 2000]. Tradycyjna teoria opierająca się na homogeniczności preferencji oraz na zachowaniach egoistycznych prowadziła do wniosku o pojedynczej równowadze grupowej, zatem powyższe wyniki wskazywały na konieczność rewizji jej założeń.

Z czasem względem tradycyjnej teorii formułowano coraz więcej zarzutów - także na gruncie teoretycznym. Oferowane przez nią wyjaśnienia okazały się zbyt jednostronne, abstrahowały od dużej złożoności rzeczywistości społecznej. Zanadto upraszczały definicję sytuacji społecznej, przyrównując ją do jednorazowej, niezależnej od kontekstu wymiany rynkowej. Przedstawiały społeczeństwo jako zbiór zatomizowanych jednostek, podczas gdy w rzeczywistości ludzie uczestniczą w relacjach społecznych, sieciach i organizacjach [Ostrom, Ahn, 2007].

E. Ostrom [1997] zauważa, że model pełnej racjonalności jednostki faktycznie sprawdza się w odniesieniu do działań w warunkach rynkowych, które charakteryzują się współzawodnictwem, konfliktem interesów oraz krótkim horyzontem czasowym. Jednakże rzeczywiste dylematy społeczne to często sytuacje 
o długim horyzoncie czasowym, ze skomplikowanymi zależnościami pomiędzy aktorami. Wobec tego nie można oczekiwać, że jednostka postawiona przed dylematem społecznym będzie dokonywać kompletnych kalkulacji, oraz że jej decyzja będzie uzależniona tylko od struktury bodźców, tak jak przewiduje TRW I generacji [Ostrom, 2010].

Odpowiedzią metodologiczną na powyższe problemy był rozwój od lat 80 . instytucjonalizmu racjonalnego wyboru (dalej: IRW), zwanego również teorią racjonalnego wyboru II generacji ${ }^{5}$. Według jednego z polskich przedstawicieli tego nurtu, w porównaniu do TRW I generacji stosuje on: „rozszerzoną znacznie (...) koncepcję racjonalności ograniczonej, która operuje niedoskonałą, ale uczącą się powoli (np. norm podwyższających poziomy społecznej kooperacji) jednostką ludzką, działającą w gąszczu różnego rodzaju reguł instytucjonalnych" [Chmielewski, 2011, s. 269].

Do najważniejszych wyróżników współczesnego IRW zalicza się m.in. [North 1990; Hall i Taylor 1996; Hodgson 1998; Chmielewski 2011; Pieliński 2014]:

- uznanie wielkiej złożoności i kontyngencji rzeczywistości społecznej, istotnego wpływu wielu czynników kontekstowych; odejście od prostych, jednoznacznych wyjaśnień i prognoz,

- wzbogacony model wyboru jednostki - TRW II generacji akceptuje fakt ograniczonej racjonalności jednostki w wielu skomplikowanych sytuacjach decyzyjnych. Ograniczona racjonalność polega, po pierwsze, na sięganiu do utrwalonych heurystyk, norm i reguł; po drugie, na "sekwencyjnym podejmowaniu decyzji w świetle tego, czego [jednostki - przyp. M.G.] uczą się o sytuacji" [Chmielewski, 2011, s. 312]; po trzecie, na próbach zmiany sytuacji - przykładowo, na zmianie

5 P. Chmielewski [2011] określa ten szeroki nurt także określeniem „peryferie wyboru racjonalnego". struktury gry poprzez komunikację z innymi jej uczestnikami. Ostrom [2000] postuluje stosowanie podejścia behawioralnego i ewolucyjnego, które dopuszczają oprócz pełnej racjonalności ekonomicznej również inne rodzaje racjonalności oraz uczenie się jednostek,

- rolę interakcji społecznych - pełnią one podobną rolę, jak transakcje w starym instytucjonalizmie J. Commonsa [Commons 1931]. To w nich instytucje "stają się faktem”. Interakcje mają charakter strategiczny - jednostka działa w oparciu o oczekiwania co do zachowań pozostałych uczestników, kształtowane na bazie dotychczasowych doświadczeń i zinternalizowanych reguł. Z drugiej strony, wynik interakcji i ocena tego wyniku przez jednostkę oddziałują zwrotnie na oczekiwania i na postrzeganie obowiązujących reguł. Poprzez ciągłe uczenie się, każda interakcja niesie konsekwencje dla przyszłych działań.

\section{Współczesna teoria działań zbiorowych}

Model w pełni racjonalnej jednostki powinien zostać zarezerwowany dla prostych, rywalizacyjnych sytuacji przypominających wybory rynkowe. W przypadku dylematów społecznych z powtarzalnymi wyborami, charakterystycznych dla trwałych struktur społecznych, jednostki przyjmują raczej perspektywę długookresową i proste, deterministyczne wyjaśnienia ich działań nie znajdują zastosowania. Jednostki w procesie uczenia się zauważają, że jednostronne, rywalizacyjne zachowania okazują się często niekorzystne. Różnorodność typów ludzkich, począwszy od egoistów do osób chętnie współpracujących, powoduje, że część ludzi będzie racjonalnie podejmować próby przezwyciężenia dylematów społecznych, które w krótkim okresie będą polegały na rezygnacji z części interesu własnego. Teoretyczne 
wyjaśnienie tego zjawiska nie powinno jednak ograniczać się do takich koncepcji jak „długookresowa racjonalność" lub altruizm. Wielu grupom nie udaje się bowiem w ogóle podjąć działań zbiorowych albo z różnych powodów współpraca w pewnym momencie ulega zerwaniu. Pożądana teoria działań zbiorowych powinna dostarczać mechanizmów wyjaśniających tę różnorodność wyników [Ostrom, 1997; 2010, s. 156].

Mając na uwadze powyższe zastrzeżenia, Ostrom postuluje tworzenie złożonych modeli behawioralnych, które pozwolą odpowiedzieć na zasadnicze pytanie: w jaki sposób indywidualna gotowość do współpracy może zostać wykorzystana do podjęcia działań zbiorowych i do budowy instytucji, które takie działania będą wzmacniać? [Ostrom, 2000, s. 138]. Modele w ujęciu Ostrom opierają się na rekonceptualizacji sytuacji działania zbiorowego, na którą składają się:

1. Początkowe modele mentalne i zinternalizowane heurystyki, normy i reguły.

2. Szeroka grupa czynników kontekstowych, dotyczących:

- właściwości grupy (rozmiar, heterogeniczność, możliwość komunikacji, relacje władzy i przywództwa, dotychczasowe doświadczenia, zgoda co do celu działania itd.),

- właściwości dobra zbiorowego (jego rzadkość, przewidywalność, funkcja produkcji i dystrybucji, charakter praw własności, mobilność itd.) [Ostrom, 1997; 2003].

Wymienione czynniki należy analizować łącznie, gdyż dopiero jako kombinacje konstytuują warunki podejmowania działań zbiorowych. Każda z kombinacji będzie wymagała od uczestników innych strategii, a instytucje skuteczne w jednym otoczeniu mogą nie zapewnić współpracy w zmienionych warunkach. W rezultacie, zdaniem Ostrom, badacze społeczni zamiast szukać jednej, dużej teorii działań zbiorowych, powinni rozwijać rodzinę teorii, które będą „uwzględniać bogate wzajemne oddziaływania pomiędzy naturą do- bra, reżimem praw własności, systemem rządzenia stosowanym do tworzenia nowych reguł oraz wynikającej z niego struktury wypłat. Należy uwzględnić wszystkie te czynniki, aby uzyskać empirycznie uzasadnione wyniki" [Ostrom, 2003, s. 262]. Jak zwraca uwagę Ostrom, teoria Olsona, która miała w jego zamierzeniu stanowić ogólną teorię działań zbiorowych, obecnie okazuje się jedną teorią z tej rodziny [ibidem].

Poniżej opisano, w jaki sposób współczesna teoria działań zbiorowych traktuje normy, instytucje i sieci relacji społecznych jako mechanizmy umożliwiające współpracę. W pierwszej kolejności zostaną opisane normy i instytucje jako elementy sytuacji działania zbiorowego, a następnie zostanie przedstawiona koncepcja kapitału społecznego Ostrom i Ahna.

\subsection{Normy}

Ostrom definiuje normy jako „wewnętrzne wartościowanie pewnych zachowań jako pozytywnych lub negatywnych", uogólnione względem konkretnych sytuacji działania [Ostrom, 1997, s. 9]. Normy są wyuczane w działaniu i w obserwacji - jednostka będzie skłonna przyjmować $w$ działaniu te normy, które w przeszłości prowadziły do sukcesu, jak i te, które postrzega jako słuszne same w sobie. Motywacja do przestrzegania norm ma przede wszystkim charakter wewnętrzny i wiąże się z nagrodami i karami, które przyznajemy sami sobie, w sumieniu, za określone zachowania.

Wspólne doświadczenia grupy powodują, że wśród jej członków wykształca się pewien poziom podzielanych norm, pomimo różnic w ich internalizacji, a wpływ norm na działanie nabiera także ponadjednostkowego charakteru. Niektóre normy (np. norma wzajemności, sprawiedliwości) wpływają na tworzenie strategii działania, gdyż wytwarzają oczekiwania co do podejmowania słusznych zachowań przez partnerów w interakcji. Złamanie normy może wiązać się z nega- 
tywnymi konsekwencjami, ale w przypadku norm, w odróżnieniu od instytucji opisanych w dalszej części tekstu, konsekwencje te nie są jasno określone i będą przyjmować często postać pogorszenia lub polepszenia reputacji jednostki. Ponieważ reputacja jest istotnym zasobem społecznym, gęste sieci z trwającymi relacjami społecznymi sprzyjają przestrzeganiu norm przez członków grupy [Ostrom i Basurto, 2009; Ostrom 2010].

Eksperymenty dylematów społecznych wskazywały na występowanie, obok racjonalnych egoistów znanych z tradycyjnej teorii, co najmniej dwóch typów jednostek działających według norm: „warunkowych współpracowników" i "chętnych do karania" [Ostrom, 2000, s. 142]. Ci pierwsi w sytuacjach decyzyjnych, jeśli oczekiwali wysokich poziomów współpracy ze strony innych uczestników, inicjowali działania kooperacyjne, pozytywne działania innych nagradzali dalszą współpracą, a negatywne - po pewnym czasie - zmianą swojej decyzji. Ci drudzy byli gotowi angażować się i poświęcać swoje zasoby na rzecz karania "gapowiczów", osób niewspółpracujących, a czasami także nagradzać osoby trwale gotowe do współpracy.

Szczególnie istotna dla dalszych rozważań jest norma wzajemności. Stanowi ją zespół kilku strategii, które polegają na tym, że za pozytywne działania podejmowane przez partnerów interakcji ludzie odwzajemniają się pozytywnie, a za negatywne - negatywnie. Dotyczą one również tego, jak formułować oczekiwania wobec kooperacyjnych zachowań innych osób. Norm wzajemności uczymy się podczas socjalizacji pierwotnej, ale też w doświadczeniach przez całe życie. Jeśli w przeszłości jednostka spotykała się często z uczciwymi osobami, to będzie skłonna stosować samemu normę wzajemności [Ostrom, 1997].

\subsection{Instytucje}

W teorii Ostrom kluczową role pełnią instytucje, pojmowane, za Commonsem i Northem, jako "reguły w działaniu” [Ostrom, 1986]. Są to powszechnie akceptowane w danej społeczności zalecenia dotyczącego tego, jakie działania są w danej sytuacji: pożądane, zakazane i dozwolone. W odróżnieniu od norm, z każdą regułą wiąże się sankcja nakładana na osoby jej nie przestrzegające. Są one również bardziej konkretne od norm - dotyczą jasno określonych sytuacji i działań. Sankcjonując określone działania, instytucje zawężają pole wyboru i w ten sposób ograniczają niepewność odnośnie działania partnerów interakcji.

W myśli Commonsa [1931, s. 652] dwa analizowane przez nas pojęcia były wręcz ze sobą tożsame - „instytucja to działanie zbiorowe na rzecz kontroli, uwolnienia i ekspansji działań indywidualnych". Znajdujemy tu istotne podkreślenie dwóch aspektów instytucji, które we współczesnej myśli nie są może tak mocno eksponowane jak ich funkcja kontrolna. Po pierwsze, instytucje dają jednostkom także wolność działania, ponieważ pozwalają uniknąć dyskryminacji, przymusu, czy nieuczciwej konkurencji, którym takie działanie mogłoby podlegać w nieuregulowanym świecie. Po drugie, organizując działania zbiorowości poszerzają zakres możliwych działań daleko poza to, co jest w zasięgu jednostek. Nowy instytucjonalizm podkreśla zwłaszcza rolę reguł nieformalnych, które są głęboko zakorzenione w historii społeczności, często mając swoje źródło w moralności. Natomiast funkcją reguł formalnych powinno być umacnianie nieformalnych konwencji, zwłaszcza w sytuacjach, gdy partnerzy interakcji są względem siebie anonimowi.

Podstawowy wniosek z powyższych rozważań jest taki, że instytucje określają reguły gry w sytuacji zbiorowego działania. Ostrom zarysowuje w tym miejscu zasadniczą różnicę pomiędzy TRW I generacji a koncepcjami IRW. Ten pierwszy jest deterministyczny; jasno określona sytuacja działania w połącze- 
niu z precyzyjnym modelem jednostki prowadzi do jednoznacznych wyników ${ }^{6}$ :

Struktura sytuacji działania a Model działającej

$$
\text { jednostki }=\text { Wyniki }
$$

Tymczasem w IRW, struktura sytuacji działania jest dopiero tworzona przez zestaw reguł, do których stosują się jej uczestnicy, w połączeniu z obiektywnymi prawami fizyki oraz z pewnymi prawami behawioralnymi, opisującymi postępowanie jednostek:

\section{Reguły a Prawa fizyki a Prawa behawioralne = Struktura sytuacji działania}

Struktura sytuacji działania stwarza możliwości wyboru dla jednostek, a ostateczne wyniki nie mogą zostać z góry jednoznacznie przewidziane. W odróżnieniu od tradycyjnej teorii, nie znajdujemy tu deterministycznych mechanizmów [Ostrom, 1986; Pieliński, 2014].

\subsection{Instytucjonalizacja sytuacji działania zbiorowego}

Problemem teoretycznym, przed którym staje w tym momencie teoria działań zbiorowych jest mechanizm tworzenia, zmiany, a także implementacji reguł instytucjonalnych. Kluczowe dla wyjaśnienia tych zjawisk jest spostrzeżenie, które znajdujemy jeszcze w pracy Olsona [2012, s. 68-82] - efektywne instytucje, zapewniające grupie wysoki poziom współpracy lub dostarczenia dóbr publicznych, są same w sobie dobrem publicznym. Aby je zaprojektować, ustanowić, a następnie kontrolować i egzekwować ich przestrzeganie, konieczne jest podjęcie działania zbiorowego, które może być nieosiągalne z powodów opisanych w części 1 niniejszego artykułu. Mamy tu zatem do czynienia z dylematem społecznym II rzędu [por. North, 1990, rozdz. 2 i 7].

Jednakże również $w$ tym miejscu doświadczenia wielu społeczności lokalnych oraz wyniki eksperymentów przekonują o zdolności

6 Symbol a oznacza pewną nieokreśloną zależność jednostek do przełamywania tragedii działania zbiorowego [Ostrom, 2000]. Po pierwsze, działania zbiorowe rzadko kiedy podejmowane są w społecznej próżni, przez anonimowe względem siebie jednostki. Zazwyczaj występują już pewne struktury lub wcześniejsze reguły, które mogą zostać wykorzystane w celu koordynacji działań. Po drugie, ludzie są skłonni zainwestować swój czas, energię i inne zasoby na rzecz budowy takich reguł, jeśli widzą, że dotychczas osiągane przez grupę wyniki są dalekie od optymalnych.

Dla rozwoju instytucji zapewniających współpracę istotny jest pierwotny skład grupy. Początkowe występowanie w grupie dużej liczby współpracujących pokazuje wszystkim członkom korzyści ze współpracy i powoduje rozpowszechnianie się działań kooperacyjnych. W takich grupach rozwijają się mechanizmy nagród i kar oraz inne instytucje koordynujące działania. Odwrotnie, w grupach z przewagą liczebną egoistów strategia egoistyczna szybko staje się dominującą i dobra zbiorowe nie są w nich dostarczane. Grupowa funkcja "chętnych do karania" jest również nie do przecenienia, gdyż ich działania oznaczają realizację ustanowionych sankcji i w ten sposób przełamują dylemat II rzędu związany z wprowadzeniem w życie reguł grupowych. Działające w dłuższych okresach czasu procesy społecznego uczenia się i ewolucyjnej selekcji sprzyjają rozpowszechnianiu działań ukierunkowanych na współpracę także pomiędzy grupami [Ostrom, 2000].

Kluczowa dla procesu instytucjonalizacji jest możliwość bezpośredniej komunikacji pomiędzy członkami zbiorowości. Komunikacja znacząco zmienia kształt sytuacji decyzyjnej i zasadniczo sprzyja nawiązaniu trwałej współpracy. Podstawowym kanałem tego wpływu nie jest samo przekazywanie informacji na temat optymalnej strategii, lecz wymiana wzajemnych zobowiązań i ustalenie mechanizmów ich egzekwowania. Dodatkowo, dzięki komunikacji bezpośredniej dochodzi do: wzrostu zaufania i zmiany 


\section{Rysunek 1. Instytucjonalizacja sytuacji działania zbiorowego}

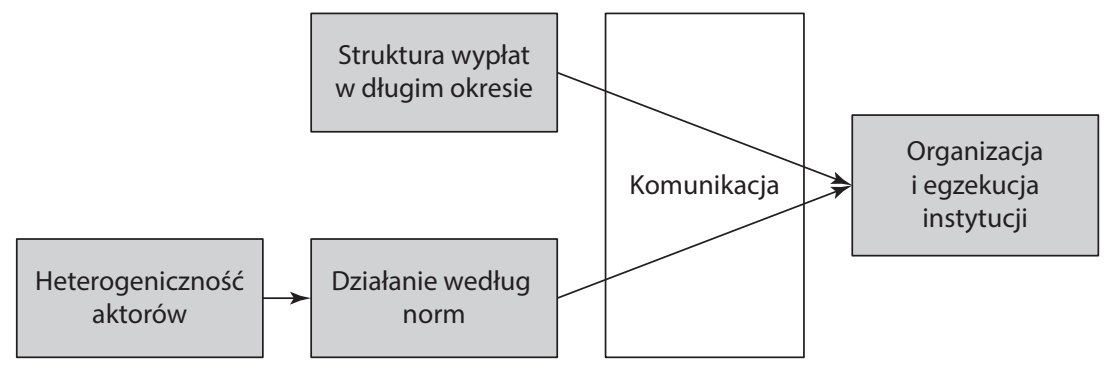

Źródło: opracowanie własne.

oczekiwań wobec pozostałych uczestników, wzmocnienia początkowych norm oraz rozwoju tożsamości grupowej [Ostrom, 1997].

Podsumowanie powyższych rozważań dotyczących instytucjonalizacji sytuacji działania zbiorowego przedstawia rysunek 1. Długookresowe korzyści oraz występowanie członków grupy działających według norm, wraz z możliwością bezpośredniej komunikacji, są decydującymi czynnikami w tym procesie.

\subsection{Kapitał społeczny jako podstawa działań zbiorowych}

W myśli Ostrom model jednostki o ograniczonej racjonalności działającej według norm znajduje połączenie z instytucjonalnym kontekstem działania w koncepcji kapitału społecznego. W koncepcji Ostrom i Ahna kapitał społeczny jest pewną „właściwością jednostek oraz ich relacji społecznych, która umożliwia rozwiązywanie problemów związanych z działaniem zbiorowym" [Ostrom, Ahn, 2007, s. 5].Wyszczególnione przez autorów trzy typy kapitału społecznego to formalne i nieformalne instytucje, sieci i wiarygodność. W ich ujęciu instytucje dotyczą przede wszystkim reguł grupowych, choć, jak zostanie pokazane, powinny one zostać uzupełnione o działanie instytucji z poziomu społeczeństwa.

Elementem stojącym pomiędzy kapitałem społecznym w jego różnych formach a podjęciem działania zbiorowego jest zaufanie. Ostrom i Ahn [1997, cyt. za: Gambetta,
2000], definiują zaufanie jako subiektywne przekonanie jednostki co do prawdopodobieństwa tego, że partner w interakcji podejmie oczekiwane działanie. Wysoki poziom zaufania ogranicza niepewność sytuacji działania, co, idąc za myślą Northa [1990, rozdz. 1-2], zwiększa szanse podjęcia działań nieegoistycznych. Natomiast wiarygodność jednostek, gęste sieci społeczne oraz istnienie reguł instytucjonalnych mogą w określonych konfiguracjach sprzyjać rozwojowi zaufania pomiędzy członkami grupy [Ostrom, Ahn, 2007].

Choć mechanizmy działania dwóch pierwszych rodzajów kapitału społecznego - reguł i sieci - można wytłumaczyć odwołując się do teorii działań zbiorowych I rzędu, czyli w kategoriach kosztów i korzyści, to znajdują one cenne wyjaśnienie w myśli instytucjonalnej. Wpływ instytucji na działanie jednostek na rzecz dobra zbiorowego przyjmuje charakter bezpośredni i pośredni. Przede wszystkim, ustalone reguły zmieniają strukturę wypłat związaną z podjęciem działania zbiorowego, wprowadzając kary i nagrody za konkretne zachowania. Jest to zatem mechanizm, który Olson opisał pod pojęciem „bodźców selektywnych”.

Nannestad i Svendsen [2005] podają dwa kolejne mechanizmy wpływu instytucji: możliwość uzyskania zadośćuczynienia w przypadku zostania oszukanym oraz wyznaczenie standardów uczciwego zachowania. To ostatnie spostrzeżenie prowadzi do pośred- 
niego, długookresowego wpływu instytucji. Regulując zachowania jednostek, jednocześnie wpływają one na wzajemne oczekiwania i zmniejszają niepewność każdego z członków grupy co do działań pozostałych. W ten sposób wtórnie zwiększają prawdopodobieństwo tego, że każda jednostka zaangażuje się w działania grupy. Aby reguły grupowe faktycznie przyczyniały się do rozwoju zaufania muszą być utwierdzane w rzeczywistych interakcjach, a nieodwołalność sankcji nie może budzić wątpliwości [Ostrom, Ahn, 2007]. W tym miejscu ujawnia się istotna rola szerszego porządku instytucjonalnego, który, przykładowo poprzez sprawny system sądowniczy, może wspierać egzekucję reguł grupowych.

Drugą formę kapitału społecznego stanowią sieci społeczne, które przejawiają się w trwałych relacjach pomiędzy podmiotami oraz w licznych i powtarzalnych interakcjach pomiędzy nimi. Podstawowym kanałem, poprzez który sieci sprzyjają rozwojowi zaufania, jest szybka i dokładna dyfuzja informacji o członkach grupy. Dzięki temu zwiększa się zakres posiadanych informacji o pozostałych uczestnikach działania zbiorowego i formułowanie oczekiwań staje się łatwiejsze. Przede wszystkim jednak, na co szczególny nacisk kładą Cook i Hardin [2000], znacząco rosną bodźce do podejmowania uczciwych działań i budowy dobrej reputacji. Dzieje się tak, ponieważ informacja o pozytywnym bądź negatywnym zachowaniu w jednej interakcji trafia do pozostałych członków całej sieci, przez co każde działanie nabiera istotnego znaczenia dla indywidualnej wiarygodności.

Trzecią formą kapitału społecznego jest ta, której nie da się wyjaśnić w kategoriach tradycyjnej teorii działań zbiorowych, a która według E. Ostrom nabiera istotnej wagi we współczesnych społeczeństwach, czyli wiarygodność. O ile reguły i sieci dotyczą całych grup, to wiarygodność jest reputacją jednostki w oczach innych osób i, do pewnego stop- nia, może obowiązywać nawet po opuszczeniu grupy przez tę jednostkę.

Wiarygodność jest blisko powiązana ze stosowaniem się w interakcjach do normy wzajemności. Konsekwentne podejmowanie uczciwych działań powoduje, że inni oczekują od nas współpracy i są bardziej skłonni nam zaufać. Wiarygodność staje się zatem kapitałem społecznym jednostki - zwiększa jej szanse na uzyskanie pozytywnych wyników w interakcjach [Ostrom, 1997]. Jeśli początkowo w grupie występują wzajemne korzyści z działań kooperacyjnych i z posiadania dobrej reputacji, mogą one skłaniać inne osoby do przyjęcia normy wzajemności - w ten sposób kapitał społeczny staje się zasobem całej grupy. W dalszej kolejności może dojść do wzrostu wiarygodności i wzajemnego zaufania, dzięki czemu grupa będzie osiągać wysokie poziomy współpracy i zbliży się do optimum społecznego. Pomiędzy trzema kategoriami: wzajemnością, reputacją i zaufaniem występują pozytywne sprzężenia zwrotne (rys. 2). Jednakże, pojawienie się w grupie działań egoistycznych może prowadzić do zmian w przeciwnym kierunku. Oznacza to, że w działaniu grupa może wytwarzać, ale również i zatracać pozytywne normy, a zaufanie nie jest dane raz na zawsze, lecz musi być podtrzymywane w działaniach [Ostrom, 2010].

Według Ostrom i Ahna [2007], we współczesnych społeczeństwach wiarygodność staje się zasobem kluczowym dla osiągnięcia współpracy, gdyż coraz więcej sytuacji ma charakter jednorazowy i zachodzi poza sieciami i jasnymi regułami. W takich warunkach zaczyna liczyć się tzw. uogólniona wiarygodność, czyli pewna uśredniona dla całego społeczeństwa reputacja. Odpowiedź na pytanie, co jest podstawowym źródłem uogólnionej wiarygodności dzieli teoretyków działania zbiorowego. Dla Ostrom i Ahna [2007] jest to przede wszystkim rozpowszechnienie normy wzajemności w społeczeństwie, podczas, gdy dla Cook i Hardina [2001] zaufanie wytwarza 


\section{Rysunek 2. Podstawowe zależności w koncepcji wiarygodności}

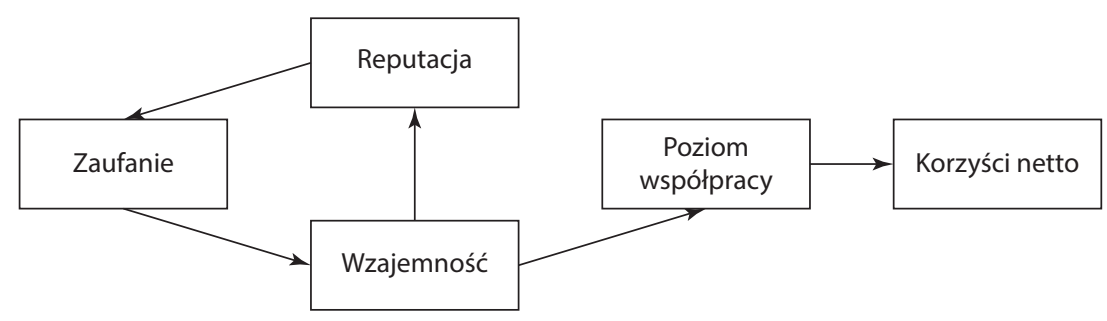

się w sieciach relacji i poza nimi nie istnieje. Rozwiązanie leży prawdopodobnie gdzieś pośrodku - uogólniona wiarygodność zależy od tego, w jakim stopniu oczekujemy, że anonimowi dla nas uczestnicy działania zbiorowego zastosują się do normy wzajemności. Z kolei to oczekiwanie jest pochodną dotychczasowych doświadczeń, zbieranych w dużej mierze podczas funkcjonowania $w$ sieciach społecznych. Warto dodać w tym miejscu uwagę Northa, który podkreśla rolę instytucji formalnych, zapewniających egzekucję postanowień wobec braku nieformalnej kontroli społecznej [North, 1990, rozdz. 6].

Rozróżnienie na zaufanie wewnątrzgrupowe i uogólnione prowadzi do całej gamy komplikacji, które mogą nastąpić w procesach tworzenia kapitału społecznego [por. Gagacki, 2013]. Po pierwsze, te dwa typy zaufania mogą być względem siebie konfliktowe, na co zwrócił uwagę Putnam [2000], pisząc o kapitale wiążącym i kapitale pomostowym. W szczególności, silne i gęste sieci relacji wewnątrzgrupowych będą rozwijać kapitał społeczny tych grup, ale nie będą sprzyjać rozwojowi zaufania pomiędzy członkami całej społeczności. Wtedy zdolność do podejmowania działań zbiorowych będzie ograniczona do już istniejących, utrwalonych grup.

Kolejny wrażliwy punkt odnajdujemy w relacji pomiędzy regułami a normami. Normy, jako mechanizmy wewnętrznej kontroli, mają tendencję do trwałości i nie wymagają kosztownych mechanizmów moni- toringu i egzekucji. Z kolei reguły są bardziej podatne na zmiany, a nadmierna regulacja i kontrola zachowań przez instytucje może prowadzić do obniżenia poziomu zaufania, gdyż członkowie grupy będą czuli, że inni im nie ufają. Poza tym normy są uogólnione, a zatem będą prędzej służyć całej zbiorowości niż reguły, których ustalanie wiąże się z rozkładem siły przetargowej w grupie.

Wreszcie, dominacja reguł formalnych w otoczeniu instytucjonalnym może mieć niekorzystne efekty dla kapitału społecznego. Sam fakt zewnętrznego przymusu okazuje się działać dysfunkcjonalnie na zaufanie i współpracę. Występuje tu zjawisko „pokusy nadużycia": skoro publiczne instytucje dbają o wzajemność i zaufanie, to my-obywatele prywatnie już nie musimy się o to troszczyć. Tymczasem normy i reguły wypracowane w działaniu przez społeczność stanowią jej kapitał społeczny i wzmacniają zaufanie oraz zdolność do współpracy.

\section{Podsumowanie}

W artykule zaprezentowano współczesną, instytucjonalną teorię działań zbiorowych, która w odróżnieniu od tradycyjnego podejścia Olsona dostarcza wyjaśnień zróżnicowanej zdolności grup do podejmowania działania. Za Hardinem [1982, s. XIII] można stwierdzić, że o ile tradycyjna teoria ujmowała problem w kategoriach gry logicznej, to jej nowoczesna wersja przypomina raczej „antropologiczną analizę relacji". W pierwszym 
Tabela 1. Różnice pomiędzy tradycyjną i współczesną teorią działań zbiorowych

\begin{tabular}{|l|l|l|}
\hline \multicolumn{1}{|c|}{ Wymiar analizy } & \multicolumn{1}{c|}{ Teoria tradycyjna } & \multicolumn{1}{c|}{ Teoria współczesna } \\
\hline Racjonalność agentów & Pełna & Ograniczona, rola norm \\
\hline Preferencje & Homogeniczne & Heterogeniczne \\
\hline Horyzont czasowy & Krótki, działanie jednorazowe & Długi, działanie strategiczne \\
\hline Instytucje & Mało istotne, egzogeniczne & Kluczowe, endogeniczne \\
\hline Wynik działania & Pojedyncza równowaga & Wiele punktów równowagi \\
\hline Promowanie współpracy & Bodźce & Zaufanie, interakcje \\
\hline
\end{tabular}

Źródło: opracowanie własne na podstawie [Kahan, 2002, s. 3].

przypadku wynik gry był jednoznaczny w zależności od parametrów dotyczących wypłat mogło dojść do działania zbiorowego lub nie, przy czym w przewidywaniach dominował wynik negatywny. W drugim, możliwość podjęcia działania zbiorowego jest dostępna nawet bardzo dużym grupom, jednakże ex ante nie da się tego jednoznacznie określić. Wielość czynników występująca w sytuacji działania powoduje, że badacze w swoich predykcjach mogą operować jedynie pewnymi przybliżeniami. Różnice pomiędzy obiema generacjami teorii działań zbiorowych zostały podsumowane w tabeli 1.

Należy podkreślić doniosłość ewolucji teorii działań zbiorowych z punktu widzenia zarówno rozwoju nauk społecznych, jak i praktyki zarządzania publicznego. Lepsze wyjaśnienie mechanizmów stojących za samoorganizacją zbiorowości pozwoliło na

\section{Literatura}

Chmielewski P. (2011). Homo agens. Instytucjonalizm w naukach społecznych, Warszawa: POLTEXT.

Commons J. R. (1931). "Institutional Economics", American Economic Review, t. 21.

Cook K. S., Hardin R. (2001). "Norms of cooperativeness and networks of trust", w: M. Hecheter, K-D. Opp (red.), Social Norms. New York: Russell Sage Foundation.

Defourny J., Nyssens M. (2013). „Social innovation, social economy and social enterprise: what can the European debate tell us?", w: F. Moulaert, D. MacCallum, A. Mehmood (red.), The international handbook on social innovation : collective action, social learning and transdisciplinary research. Cheltenham, Edward Elgar. skuteczne rozwiązywanie wielu problemów społeczności lokalnych. Natomiast, jak argumentują Nyssens i Petrella [2015], na gruncie teoretycznym można znaleźć liczne podobieństwa między podejściem Elinor Ostrom oraz analizami sektora ekonomii społecznej i solidarności. Obie koncepcje cechuje odrzucenie klasycznych dychotomii państwo-rynek, publiczny-prywatny oraz dostrzeżenie wielości form własności i policentrycznej organizacji społeczeństwa. Jako takie stanowią one szansę dla nauk społecznych, szczególnie w kontekście wyzwań stojących przed gospodarką opartą na wiedzy, w której społeczne uczenie się i zarządzanie informacją jest kluczowym czynnikiem rozwoju. Efektywne i trwałe rozwiązanie wielu problemów ekonomicznych i społecznych może leżeć na pośrednim - grupowym poziomie koordynacji.

Dixit A. (1999). „Mancur Olson - Social Scientist”, The Economic Journal, nr 109.

Dougherty K.L. (2003). „Public goods theory from eighteenth century political philosophy to twentieth century economics", Public Choice, nr 117.

Gagacki J. (2013). „Kapitał społeczny i kultura zaufania", Ekonomia społeczna, nr 1(6).

Hall P., Taylor R. (1996). „Political Science and the Three New Institutionalisms", Political Studies, t. 44.

Hardin G. (1968). "The Tragedy of the Commons", Science, $\mathrm{nr} 162$.

Hardin R. (1971). "Collective action as an agreeable n-prisoners' dilemma", Behavioral Science, nr 16(5).

Hardin, R. (1982). Collective Action. Baltimore: The Johns Hopkins University Press.

Hausner J. (2007). „Ekonomia społeczna jako sektor gospodarki", Ekonomia Społeczna, nr 1. 
Hodgson G. M. (1998). ."The Approach of Institutional Economics", Journal of Economic Literature, nr 36(1).

Kahan D. M. (2002). „The Logic of Reciprocity: Trust, Collective Action, and Law", John M. Olin Center for Studies in Law, Economics, and Public Policy Working Papers, nr 281.

Nannestad P., Svendsen G. T. (2005). Institutions, culture, and trust, referat wygłoszony na konferencji "Quality of Government: What it is, How to get it, Why it matters", Gothenburg, Szwecja, 17-19.11.2005.

North D. C. (1990). Institutions, Institutional Change and Economic Performance. New York: Cambridge University Press.

Nyssens M., Defourny J. (2014). „The Breakthrough of Social Enterprise: Conceptual Clarifications", L'Option de Confrontations Europe, 01

Nyssens M., Petrella F. (2015). "The Social and Solidarity Economy and Ostrom's approach to common pool resources: Towards a better understanding of institutional diversity?", w: J.-L. Laville, D. Young, P. Eynaud (red.), Civil Society, the Third Sector and Social Enterprise: Governance and Democracy. Routledge: Oxford.

Olson M. (2012/1971). Logika działania zbiorowego. Dobra publiczne i teoria grup. Warszawa: Wydawnictwo Naukowe SCHOLAR.

Ostrom E. (1986).,An Agenda for the Study of Institutions ${ }_{\text {II }}$ Public Choice, nr 48(1).

Ostrom E. (1987). "The Implications of the Logic of Collective Inaction for Administrative Theory", Work- shop in Political Theory and Policy Analysis Working Paper, W87-3.

Ostrom E. (1998). „A Behavioral Approach to the Rational Choice Theory of Collective Action: Presidential Address, American Political Science Association", The American Political Science Review, nr 92(1).

Ostrom E. (2000). „Collective Action and the Evolution of Social Norms", The Journal of Economic Perspectives, $\mathrm{nr}$ 14(3).

Ostrom E. (2003)..,How Types of Goods and Property Rights Jointly Affect Collective Action", Journal of Theoretical Politics, nr 15(3).

Ostrom E. (2010). „Analyzing Collective Action”, Agricultural Economics, t. 41, Issue Supplement S1.

Ostrom E., Ahn T. K. (2007). .The meaning of social capital and its link to collective action", Workshop in Political Theory and Policy Analysis Working Paper, nr W07-19.

Ostrom E., Basurto X. (2009). „The Evolution of Institutions: Towards a New Methodology", Workshop in Political Theory and Policy Analysis Research Paper, nr 2009-07-01.

Pieliński B. (2014). „From polycentricity analysis to poverty analysis. Using IAD in social policy", Problemy Polityki Społecznej. Studia i Dyskusje, nr 25(2).

Putnam R. (2000). Bowling alone: the collapse and revival of American community. Nowy Jork: Simon and Schuster.

\section{Why do groups manage to take action? Presentation of the theory of collective action of Elinor Ostrom}

Summary: M. Olson in „The Logic of Collective Action” noted that the actions of individuals in favour of groups often standed in conflict with their selfish interests. It makes it difficult to undertake collective action and means that results optimal from the point of view of the whole group are not necessarily achieved. For this reason, the theory explaining the mechanisms of collective action is of great importance. The purpose of this article is to explain in theoretical terms the conduct of collective action on the basis of contemporary institutional thought, and above all, works of E. Ostrom.

The article is purely theoretical. It explains the assumptions of I and II generation of the rational choice theory and shows how these lead to mechanisms of collective action. The modern theory of collective action of E. Ostrom enhances the concept of an acting individual with the elements explaining the interactions and long-term relationships between actors - norms, institutions and social capital. As a result, it is able to consistently describe the institutionalization of a situation of collective action and can be applied to a variety of social problems.

Keywords: collective action, social capital, rational choice theory, institutionalism, Elinor Ostrom.

\section{Prawa autorskie i licencja / Copyright and License}

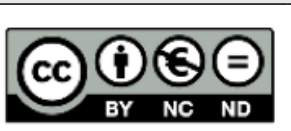

Artykuł opublikowano na licencji Creative Commons

Uznanie autorstwa - Użycie niekomercyjne - Bez utworów zależnych 3.0 Polska http://creativecommons.org/licenses/by-nc-nd/3.0/pl/

This article is published under the terms of the Creative Commons Attribution - NonCommercial - NoDerivs (CC BY-NC-ND 3.0) License http://creativecommons.org/licenses/by-nc-nd/3.0/ 